\title{
Zircon U-Pb-Hf Isotope Constraints \\ on the Paleoproterozoic Crustal Evolution of the Aravalli Orogen, NW India
}

\author{
PARAMPREET KAUR ${ }^{1 *}$, ARMIN ZEH² AND NAVEEN \\ CHAUDHRI $^{1}$ \\ ${ }^{1}$ Department of Geology, Panjab University, Chandigarh, \\ India. (*correspondance: param.geol@gmail.com) \\ ${ }^{2}$ Karlsruher Institut für Technologie, Karlsruher, Germany.
}

The conventional whole-rock isotope data provide limited information on the sources of granitoids, particularly when they are severely altered by post-crystallisation processes [e.g., 1-2]. In this context, combined zircon U-Pb-Hf isotopes in conjunction with elemental geochemical data has emerged as a powerful approach to understand sources of such granitoids [e.g., 3-5].

Zircon in situ U-Pb-Hf isotope and whole-rock elemental data unravel two significant discrete late Palaeoproterozoic granitoid emplacement events at 1860-1810 Ma and 1730$1700 \mathrm{Ma}$ in the northern Aravalli orogen. The former magmatic event is recorded by calc-alkaline Andean-type continental arc granitoids, which have been derived from garnet-free and plagioclase-rich sources at shallow depths. The occurrence of 3.3-2.5 Ga inherited zircon grains, 3.0-2.6 Ga Hf-Nd model ages along with significant variation in initial zircon-Hf $\left(\varepsilon \mathrm{Hf}_{\mathrm{t}}=-3.7\right.$ to -9.0$)$ indicate reworking of heterogeneous Archaean crust during the late Palaeoproterozoic. The younger magmatic event (1730-1700 $\mathrm{Ma})$ is recorded by variably metasomatised granitoids. These rocks show typical A-type granite characteristics $(\mathrm{Ga} / \mathrm{Al}>$ $2.5, \mathrm{Nb}+\mathrm{Y}>60 \mathrm{ppm}$, high Fe-number, REE, and HFSE). The zircon $\mathrm{Hf}$ isotope and whole-rock trace element data indicate that the magmas for these A-type granites were originated from two distinct sources; those with subchondritic $\varepsilon \mathrm{Hf}_{\mathrm{t}}$ values, by partial melting of $1.85 \mathrm{Ga}$ calc-alkaline granitoids

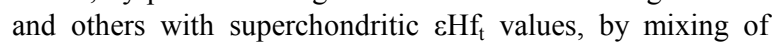
felsic crustal and mafic melts. The granites were generated in a post-collisional setting due to slab break-off, whereby the asthenosphere flowed into the slab window leading to partial melting of predominately $1.85 \mathrm{Ga}$ granitoid crust accompanied by injection of mantle-derived mafic melts.

[1] Anderson, T. et al. (2007) Lithos 93, 273-287. [2] Lauri, L.S. et al. (2011) J. Geol Soc. London 168, 201-218. [3] Zeh, A. et al. (2009) J. Petrol. 50, 933-966. [4] Kaur, P. et al. (2016) Precambrian Res. 281, 384-413. [5] Guitreau, M. et al. (2017) Precambrian Res. 302, 33-49. 